\title{
Strategi meminimalkan beban kognitif eksternal dalam pembelajaran matematika berdasarkan load cognitive theory
}

Rino Richardo

Universitas Alma Ata, Indonesia

E-mail: rinorichardo@almaata.ac.id

Rima Aksen Cahdriyana

Universitas Ahmad Dahlan, Indonesia

Email: rima.cahdriyana@pmat.uad.ac.id

\begin{abstract}
Abstrak
Memahami objek, konsep, prosedur merupakan salah satu tujuan mempelajari pelajaran matematika disekolah. Muatan materi yang cendrung kompleks dengan elemen-elemen yang abstrak menjadi masalah bagi siswa sehingga memunculkan beban kognitif, diantaranya adalah beban kognitif eksternal. Tujuan dari penelitian ini untuk menunjukkan beberapa strategi yang perlu diperhatikan dalam mendesain pembelajaran matematika agar dapat meminimalkan beban kognitif eksternal. Penelitian ini berupa studi kepustakaan (library research). Teknik pengumpulan data dalam penelitian ini, dilakukan dengan melakukan penelusuran referensi secara online melalui beberapa sumber basis data Google Cendikia, ERIC Institute of Education Science, serta Science Direct. Analisis data dalam penelitian ini menggunakan metode analisis isi (content analysis). Hasil kajian dalam studi ini terdapat 8 strategi dalam mendesain pembelajaran matematika untuk meminimalkan beban kognitif eksternal diantaranya The Goal-Free Effect, The
\end{abstract}


Worked Exampel Effect, The Split-Attention Effect, The Modality Effect, The Redundancy Effect, The Element Interactivity Effect, The Imagination Effect dan The Guidance Fading Effect.

Kata Kunci: CLT, Beban, Kognitif, Eksternal, Matematika.

\begin{abstract}
Understanding objects, concepts, procedures is one of the goals of studying mathematics in school. Material content that tends to be complex with abstract elements becomes a problem for students so that it creates cognitive loads, including external cognitive loads. The purpose of this study is to show several strategies that need to be considered in designing mathematics learning in order to minimize external cognitive load. This research is in the form of library research (library research). The data collection technique in this study was carried out by searching for references online through several Google Cendikia database sources, ERIC Institute of Education Science, and Science Direct. Analysis of the data in this study using content analysis method. The results of the study in this study there are 8 strategies in designing mathematics learning to minimize external cognitive load including The Goal-Free Effect, The Worked Exampel Effect, The Split-Attention Effect, The Modality Effect, The Redundancy Effect, The Element Interactivity Effect, The Imagination Effect and The Guidance Fading Effect.
\end{abstract}

Keywords: CLT, Load, Cognitive, External, Mathematics

\title{
Pendahuluan
}

Proses berpikir merupakan sebuah proses yang melibatkan unsur-unsur kognitif didalam momori berpikir manusia. Proses ini kemudian dikenal dengan Modal Model dengan melibatkan sistem memori manusia, yaitu memori pengindraan (sensory memory), memori pekerja (working memory) dan, memori jangka panjang (long term memory) (Ausubel, 1978). Ketiga sistem memori ini berkerja dalam rangkaian aktivitas berpikir. Secara sederhana, aktivitas tersebut diawali oleh sensory memory dengan menangkap informasi, selanjutnya working memory menerima informasi, memahami, memproses hingga mengkonstruksi menjadi sebuah pengetahuan dan disimpan di dalam longterm memory. Upaya dalam menerima informasi hingga mendapatkan sebuah pengetahuan dapat menjadi beban kognitif siswa pada proses pembelajaran atau memecahkan masalah matematika. Sehingga guru perlu mengetahui cara dalam mengembangkan desain instruksional yang mampu meminimalkan 
beban kognitif siswa, agar materi dapat diproses dan dikonstruksi menjadi pengetahuan baru yang bermakna.

Berbicara terkait dengan beban kogntif, tidak terlepas dari sebuah teori yang dinamakan Teori beban kognitif. Teori ini berdasar pada susunan kognitif manusia (Sweller et al., 2011). Ada tiga hal yang menjadi sumber beban kognif, yaitu kognitif instrinsik (intrinsic cognitive load); (2) beban kognitif ekstrinsik (extrinsic cognitive load) dan (3) beban kognitif konstruktif (german cognitive load). Beban kognitif intrinsik berkaitan dengan tingkat kompleksitas informasi atau materi yang dipelajari, beban kognitif ekstrinsik terkait dengan bagaimana cara atau teknik materi itu disampaikan (Sweller \& Chandler, 1994). Sedangkan beban kogitif konstruktif merupakan proses kognitif yang relevan dengan pemahaman materi yang sedang dipelajari dan proses konstruksi (akuisisi skema) pengetahuan (Retnowati, 2008). Beban kognitif intrinsik dalam hal ini bersifat tetap, tidak dapat dimanipulasi, berupa informasi/materi pelajaran yang akan disampaikan. Sementara beban kognitif ekstrinsik dapat dimanipulasi, tergantung bagaimana penyajian materi, metode, strategi, media yang digunakan dalam pembelajaran, sehingga materi pelajaran dapat diterima dengan baik oleh siswa. Ketika materi dapat disajikan dengan baik, artinya beban kognitif ekstrinsik akan semakin menurun. Akibatnya beban kognitif konstruktif akan meningkat, sehingga memudahkan siswa untuk memproses materi menjadi sebuah pengetahun yang bermakna. CLT juga merupakan teori dalam membuat atau mengembangkan desain instruksional berdasarkan pengetahuan kognisi manusia. Tujuannya bagaimana informasi/materi yang disampaikan kepada siswa dapat diterima, diproses dengan baik, sehingga menghasilkan konsep pengetahuan yang akan tersimpan dengan baik di memori jangka panjang. Jika pengetahuan tersebut merupakan pengetahuan awal (prior knowledge), maka akan mudah untuk dipanggil kembali sebagai pengetahuan prasayarat (prerequisite knowledge) untuk mengolah infomasi yang sedang dihadirkan, sehingga akan mudah untuk mengolah informasi baru tersebut menjadi skema pengetahuan baru yang akan disimpan kembali di memori jangka panjang.

Oleh karena itu, dalam pembelajaran guru diharapkan mampu mendesain pembelajaran dengan konsep meminimalkan beban kognitif terutama beban kognitif eksternal. Karena beban kognitif ini yang dapat dimanipulasi oleh guru, sehingga dapat membantu siswa dalam proses pembelajaran, khususnya matematika. Tujuan dari penelitian ini untuk membahas beberapa strategi yang perlu diperhatikan dalam mengembangkan desain pembelajaran matematika untuk meminimalkan beban kognitif eksternal. 


\section{Metode}

Penelitian ini menggunakan jenis penelitian yang berupa studi kepustakaan (library research). Studi pustaka berkaitan dengan kajian teoritis berdasarkan data berupa catatan, buku, makalah atau artikel, jurnal dan referensi literatur ilmiah lainnya (Zen, 2004 ; Sugiono, 2012). Literatur ilmiah yang menjadi bahan kajian dalam penelitian ini berupa buku, jurnal serta artikel-artikel ilmiah nasional terakreditasi, artikel ilmiah internasional maupun yang bereputasi yang terkait dengan topik yang dipilih. Teknik pengumpulan data dalam penelitian ini, dilakukan dengan melakukan penelusuran referensi secara online melalui beberapa sumber basis data. Penulis menggunakan 3 sumber basis data diantaranya Google Cendikia, ERIC Institute of Education Science, serta Science Direct.

Penelusuran referensi pada tiga sumber data tersebut dengan menggunakan kata kunci "Cognitive Load Theory", "Teori Beban Kogntif" "cognitive load extraneous", "Beban Kognitif Eksternal", "Pembelajaran Matematika" dan "Mathematics Learning". Artikel-artikel yang digunakan merupakan artikel yang terkait dengan tema yang akan dibahas. Sedangkan analisis data dalam penelitian ini menggunakan metode analisis isi (content analysis).

\section{Hasil dan Pembahasan}

Pada bagian ini, akan dibahas beberapa strategi-strategi yang dapat dilakukan dalam mendesain pembelajaran matematika agar dapat meminimalkan beban kogntitif eksternal, diantaranya The Goal-Free Effect, The Worked Exampel Effect, The Split-Attention Effect, The Modality Effect, The Redundancy Effect, The Element Interactivity Effect, The Imagination Effect dan The Guidance Fading Effect .

\section{The Goal-Free Effect}

Dalam konsep teori beban kognitif istilah Goal-free effect dikaitkan dengan cara penyajian materi matematika dalam hal pemberian masalah atau soal atau dikenal dengan Goal-free problems. Istilah ini juga dikenal sebagai no-goal problems yang merupakan pemberian masalah matematika dalam pembelajaran dengan tidak menentukan tujuan / jawaban akhir dari masalah tersebut (Sweller et al, 2011). 
Dalam pembelajaran konvensional biasanya para guru memberikan masalah atau soal dengan satu tujuan pertanyaan. Goal free problems memberikan metode yang berbeda dengan tidak menetukan pertanyaan yang spesifik, sebagaimana pada pembelajaran konvensional pada umumnya. Paas et al (2012) menyatakan bahwa beban kognitif eksternal dapat diminimalkan dengan memberikan penyajian masalah dengan teknik Goal free problems. Pada materi trigonometri misalnya, ketika siswa diminta menghitung salah satu sisi segitiga. sementara, goal free problem meminta siswa menghitung semua sisi-sisi segitiga yang mungkin, sehingga pertanyaan soal dapat diganti dengan kata-kata yang lebih umum seperti "Hitunglah sisi lain yang belum diketahui sebanyak mungkin” (Blegur dkk, 2017)

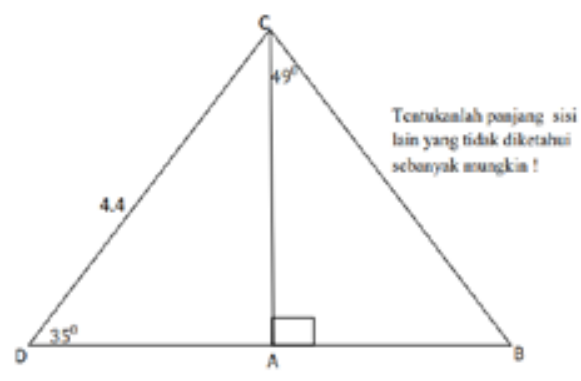

Gambar 1. Contoh Goal Free Problem (Blegur dkk, 2017)

Sebelum soal ini dibentuk dengan strategi Goal free Problem, biasanya siswa diminta menentukan salah satu sisi, misalnya berapakah panjang BC?. Pada umumnya siswa dengan kemampuan prasyarat yang rendah akan langsung beranggapan untuk menggunakan konsep phytagoras dalam penyelesaian dan mencari terlebih dahulu panjang $\mathrm{AC}$ atau $\mathrm{AB}$, atau bahkan beranggapan sisi $\mathrm{BC}$ = sisi $\mathrm{CD}$. Ada beberapa kemungkinan tahapan-tahapan yang akan dilakukan siswa, bisa saja siswa akan mencari terlebih dahulu sisi AD, dilanjutkan dengan mencari sisi AC atau sebaliknya. Selanjutnya siswa akan menentukan panjang sisi $A B$ jika siswa $A C$ telah diketahui. Masalahnya adalah jika ada langkah yang tidak berhasil ditemukan siswa, maka siswa akan mencari cara lain, jika tidak berhasil kembali maka akan begitu seterusnya. Inilah yang menjadikan proses berfikir menjadi tidak efisien. Namun demikian kondisi ini berbeda dengan siswa yang memiliki kemampuan matematika yang baik dengan kemampuan prasyarat yang cukup. Pemberian goal free problem memberikan 
pengalaman belajar bagi siswa untuk memahami dan bagaimana menyelesaikan masalah berdasarkan informasi yang diberikan sera siswa dapat mengkonstruk pemahaman terkait materi yang dipelajarinya dengan baik (Blegur $\mathrm{dkk}, 2017$ ).

\section{The Worked Exampel Effect}

Worked example merupakan salah satu strategi yang dapat digunakan dalam pembelajaran matematika yang efektif dalam meminimalkan beban kognitif eksternal serta membantu siswa yang memiliki kemampuan awal yang terbatas (Sweller et al : 2011 ; Irwansyah, Retnowati : 2019). strategi ini memudahkan siswa dalam mengkonstruksi pengetahuannya, karena dalam menyelesaikan masalah siswa diberikan langkah-langkah detail yang urut dari awal hingga menemukan solusi dari masalah yang diberikan. Urutan langkah tersebut sangat membantu siswa untuk lebih konsentrasi dan terfokus dalam memahami konsep yang sedang dipelajari. Soal yang menggunakan worked example effect, misalnya hitunglah $(\mathrm{x}+4)(3 \mathrm{x}-2)$

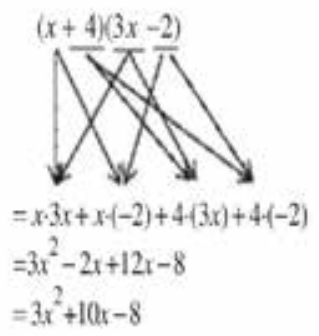

Gambar 2. Contoh Soal dengan worked example effect (Chen et al, 2019)

Berdasarkan gambar 2, jelas bahwa strategi ini memberikan langkahlangkah yang cukup detail dalam menyelesaikan soal. Jika contoh soal merupakan masalah matematika, maka diberikan langkah langkah yang berurut dan detail dalam menyelesaikannya. Misalnya, langkah 1 berupa instruksi "Baca dan pahami masalahnya dengan cermat", Langkah 2 "Tuliskan informasi penting tentang masalah tersebut", Langkah 3 "buatlah pola/rumus/ strategi penyelesaian" dan diakhir dengan Langkah 4 "membuat kesimpulan"

\section{The Split-Attention Effect / efek perhatian terpisah}

Efek perhatian terpisah merupakan bentuk penyajian materi dengan memberikan dua iformasi yang terkait secara terpisah. Efek ini seharusnya 
dihindari oleh guru dalam menyampaikan materi khususnya matematika. Menghindari efek ini terbukti mampu meminimalkan beban kogntif ekstrinsik (Sweller, 1999). Misalnya guru sedang menyampaikan materi terkait konsep hubungan antar sudut (sudut-sudut yang sehadap, bertolak belakang, bersebrangan dan lain sebagainya), maka ketika mencari besar sebuah sudut yang biasanya disajikan pada gambar, proses penjelasan biasanya ditulis pada bagian yang terpisah dari bagian gambar sudut yang dicari. Hal ini yang menimbulkan siswa akan mencermati 2 informasi yang seharusnya siswa akan lebih dapat memahami jika keduanya diintegrasikan (Teknik Integratif).
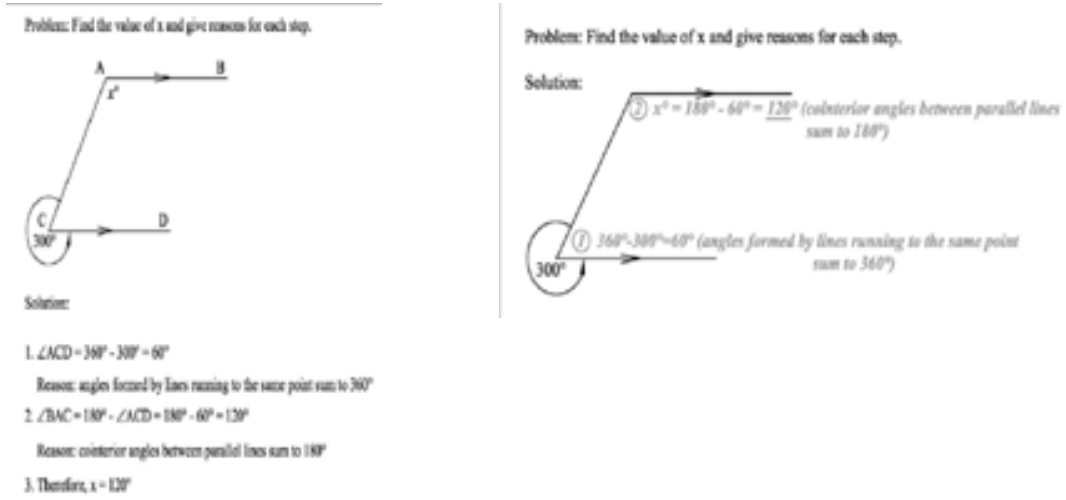

\section{Gambar 3 Efek Perhatian Terpisah dan Terintegratif (diambil dari Retnowati et al, 2008)}

Catatan lainnya bahwa efek split-attention hanya berlaku untuk sumber informasi yang tidak dapat dipahami secara terpisah. Untuk memahami gambar dan teks/penjelasannya, misalnya, keduanya hanya dapat dipahami setelah diintegrasikan

\section{The Modality Effect / Efek Modalitas}

Efek ini berkaitan erat dengan efek split-attention. Ketika dihadapkan pada dua sumber informasi yang sulit dipahami secara terpisah, maka keduanya dapat disajikan dalam modalitas yang berbeda. Satu sumber dapat disajikan secara visual, sedangkan sumber lainnya dapat disajikan secara auditorial. Penyajian modalitas ganda harus meningkatkan memori kerja yang efektif dan dengan demikian menurunkan beban kognitif eksternal (Sweller et al, 2011). Dengan demikian konsep efek modalitas lebih cendrung digunakan dalam 
menyajikan materi menggunakan multimedia. Hal ini karena multimedia berkaitan dengan visualisasi dan auditorial.

Ada alasan teoritis untuk menyarankan bahwa presentasi modalitas ganda harus meningkatkan kapasitas memori kerja yang efektif. Menurut Baddeley Model (Baddeley, 1999), memori kerja mencakup auditory loop untuk memproses ucapan dan visual-spatial sketch-pad untuk memproses materi visual. Dengan menggunakan keduanya, kapasitas memori kerja akan meningkat (Penney, 1989). Dalam pembelajaran geometri misalnya, instruksi disajikan seluruhnya secara visual dengan teks disajikan dalam bentuk tertulis. Visual-spatial sketch-pad harus digunakan untuk memproses informasi gambar dan juga harus digunakan untuk memproses teks tertulis. Teks tertulis kemudian perlu diubah menjadi bentuk pendengaran untuk diproses lebih lanjut. Saluran visual memiliki kapasitas pemrosesan yang terbatas sehingga dapat dengan mudah kelebihan beban. kebutuhan untuk awalnya memproses teks tertulis menggunakan saluran visual dan mengubah teks tertulis menjadi teks auditori (dalam bentuk suara). hal ini dapat menimbulkan beban kognitif asing yang dapat mengganggu transfer informasi ke memori jangka panjang. Sehingga hadirnya multimedia sebagai media alternatif, bahwa jika teks tertulis disajikan dalam bentuk lisan (suara), maka saluran visual tidak lagi diperlukan untuk memproses teks untuk mengubah informasi menjadi bentuk pendengaran (suara) untuk diproses lebih lanjut. sehingga konsekuensinya adalah pengurangan beban kognitif eksternal yang dibebankan pada saluran visual yang diharapkan dapat meningkatkan pembelajaran. Berdasarkan hasil penelitian (leahy, sweller : 2016) bahwa efek modalitas pada multimedia telah dengan jelas menunjukkan bahwa mempelajari bahan ajar yang menggunakan format ganda yang terdiri dari, misalnya, diagram visual dan teks auditori (lisan) dapat menghasilkan pemrosesan yang lebih efisien bila dibandingkan dengan mempelajari presentasi visual saja. Berikut gambar working memory model dan penjelasan cara kerja bagian-bagiannya ketika dihadirkan multimedia. 


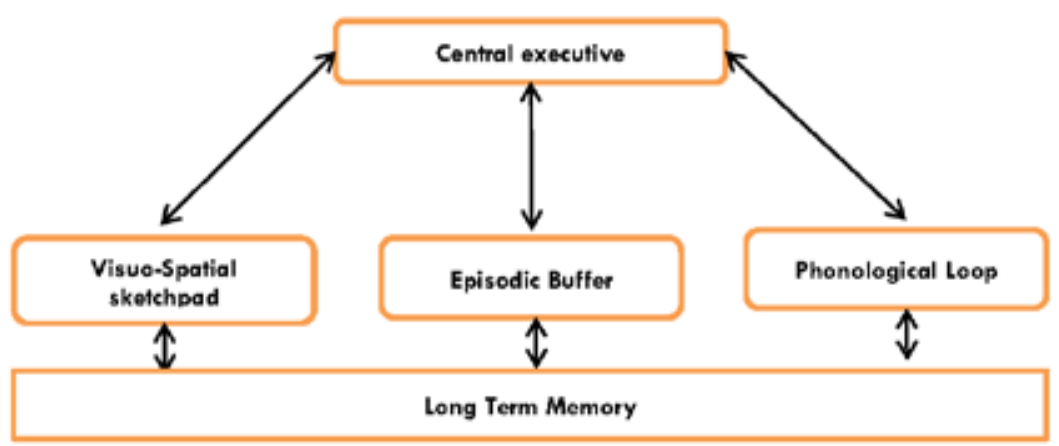

Gambar 4 Working Memory Model (diambil dari Baddeley et al, 2012)

Berdasarkan gambar 4, ada beberapa komponen didalam working memory yang bekerja dalam memproses informasi, diantaranya (1) Central Excutive, mengatur informasi apa yang menjadi perhatian kita, (2) Visuo-Spatial sketchpad, bagian yang menerima informasi berupa gambar, (3) Phonological Loop, bagian yang menerima informasi berupa suara atau tulisan, dan (4) Episodic Buffer, bagian yang menggabungkan, jika beberapa informasi yang menggunakan komponen yang sama, mereka tidak dapat maksimal, tetapi jika beberapa informasi menggunakan komponen yang berbeda, mungkin untuk melakukan keduanya sama baiknya. Efek modality yang dihasilkan oleh multimedia dalam pembelajaran yaitu informasi visual dan suara akan menjadikan beban yang ada di working memory terbagi pada dua komponen yaitu Visuo-Spatial sketchpad dan Phonological Loop dapat mengurangi beban kognitif eksternal. Sehingga wajar jika siswa merasa lebih mudah memahami informasi melalui multimedia dibandingkan konvensional.

\section{The Redundancy Effect / Efek Perulangan}

Efek perulangan terjadi ketika penambahan informasi yang berlebihan mengganggu pembelajaran. Efek tersebut hampir mirip dengan efek splitattention. Perbedaan antara kedua efek tersebut berasal dari hubungan antara berbagai sumber informasi. Dalam kasus efek split-attention, berbagai sumber informasi tidak dapat dipahami secara terpisah dan harus diintegrasikan sebelum dapat dipahami. Dalam kasus perulangan, sumber informasi dapat dipahami secara terpisah dan tidak perlu diintegrasikan agar dapat dipahami (Sweller et al, 2011). Misalnya, teks mungkin hanya mendeskripsikan ulang gambar yang dapat dipahami dengan sendirinya. Teks seperti itu berlebihan. Efek perulangan 
terjadi ketika informasi tambahan apa pun yang tidak diperlukan disajikan.

Efek perulangan disebabkan oleh pengenalan elemen berinteraksi yang tidak perlu yang mengakibatkan beban kognitif eksternal. Misalnya, jika peserta didik disajikan dengan gambar bersama dengan teks yang menggambarkan kembali gambar tersebut, mereka akan berusaha untuk memproses baik elemen yang membentuk gambar maupun elemen yang membentuk teks. Mereka cenderung mencoba menghubungkan diagram dan teks. Upaya untuk menghubungkan gambar dan teks seperti itu sepertinya tidak perlu memerlukan penggunaan memerlukan memori kerja yang dapat menimbulkan beban kognitif eksternal.
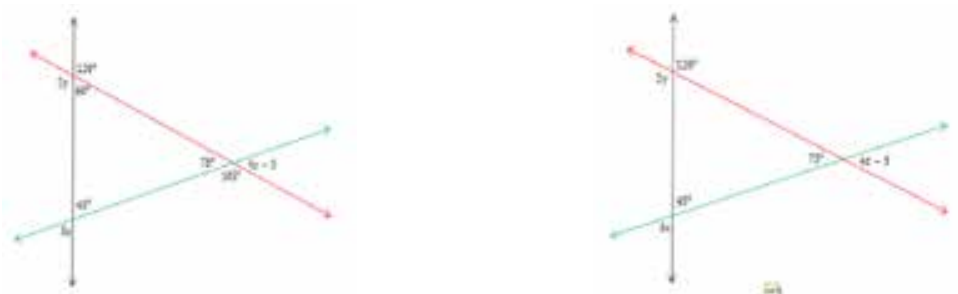

Gambar 4 contoh masalah geometri dengan efek perulangan dan tanpa efek perulangan (diambil dari Irfani \& Retnowati , 2020)

\section{The Element Interactivity Effect / Interaktivitas elemen}

Beban kognitif eksternal juga sering ditentukan oleh prosedur instruksional dan dapat diubah dengan mengubah prosedur tersebut. Interaktivitas elemen dalam materi pembelajaran adalah bagian dari prosedur instruksional, sehingga sangat menentukan tingkat beban kognitif eksternal peserta didik. Interaktivitas mengacu pada banyaknya jumlah elemen materi yang harus dipertimbangkan dan diproses secara bersamaan dalam memori kerja (Sweller, 2010). Untuk mengilustrasikan elemen interaktivitas yang terlibat dalam dua metode sebagai contoh dalam menyelesaikan konsep persamaan linier, yaitu metode kesimbangan dan metode kebalikan (Ngu et al , 2015). Contoh soal dengan Metode kesimbangan sebagai berikut

$\begin{array}{lll}\text { Baris } 1 & \mathrm{~m}+8=12 & \text { (kedua ruas ditambah }-8) \\ \text { Baris } 2 & -8-8 & \\ \text { Baris } 3 & \mathrm{~m}=4\end{array}$

Langkah Baris 1: Ada tiga elemen ( $\mathrm{m}, 8$ dan 12) dan konsep yang terlibat adalah: (1) mis angka yang tidak diketahui, (2) tanda "=" menggambarkan 
hubungan antara kiri dan kanan persamaan sehingga sama, dan (3) untuk menemukan $\mathrm{m}$, kita perlu menjaga $\mathrm{m}$ tetapi juga menjaga keseimbangan sisi kiri dan kanan sehingga apa yang dilakukan di kiri juga harus dilakukan di kanan. Pelajar dituntut untuk menangani pengetahuan konseptual dengan memahami interaksi dari tiga elemen dan konsep secara bersamaan. Baris 2: Ada satu elemen $(-8)$ dan konsep yang terlibat adalah: (1) -8 dengan +8 di sisi kiri dan (2) hal yang sama -8 harus dilakukan di sisi kanan untuk menjaga kesetaraan keduanya sisi. Di sini, interaktivitas elemen terjadi di kedua sisi persamaan. Pelajar tidak hanya perlu memproses -8 dengan +8 di sisi kiri, tetapi juga -8 dengan +12 di sisi kanan. Baris 3: Ada dua elemen ( $m$ dan 4 ) dalam solusi, jika pelajar dapat menangani interaktivitas elemen yang terlibat dalam pengetahuan konseptual (Baris 1) dan pengetahuan konseptual dan prosedural (Baris 2), elemen dalam solusi (Baris 3) akan tampak mudah.

Contoh metode kebalikan

$\begin{array}{ll}\text { Baris } 1 & \mathrm{~m}+8=12 \\ \text { Baris } 2 & \mathrm{~m}=12-8 \\ \text { Baris } 3 & \mathrm{~m}=4\end{array}$

Baris 1: Jumlah elemen dan konsep pertama dan kedua yang terlibat sama seperti dalam metode keseimbangan, tetapi konsep ketiga berbeda. Untuk menyeimbangkan persamaan, pelajar perlu menerapkan operasi kebalikan (misalnya penjumlahan adalah kebalikan dari pengurangan) saat memindahkan nilai dari satu sisi persamaan ke sisi lain. Pelajar perlu memproses pengetahuan konseptual dalam bentuk interaksi elemen-elemen ini dan konsep secara bersamaan. Baris 2: Ada tiga elemen ( $\mathrm{m}, 8$ dan 12) dan konsepnya melibatkan operasi prosedural terbalik: pindahkan +8 dari sisi kiri Baris 1 menjadi $\square 8$ di sisi kanan Baris 2 untuk mempertahankan persamaan dari keduanya sisi. Interaktivitas elemen terjadi di sisi kanan tempat $\square 8$ berinteraksi dengan 12 . Baris 3 : Tidak ada perbedaan antara metode keseimbangan dan terbalik di sini. Dalam konteks soal yang kompleks dengan berbagai variasi elemen, gabungan konsep, guru dapat memberikan langkah -langkah yang memudahkan siswa dalam memahami interaksi antar elemen dan konsep yang sedang dipelajari.

\section{The Imagination Effect / Efek Imajinasi}

Teknik imajinasi adalah yang pertama diselidiki oleh Cooper, TindallFord, Chandler, dan Sweller yang bertanya siswa membayangkan prosedur dari projek yaitu diagram dengan penjelasan yang berurutan pada setiap 
langkah pada sebuah spreadsheet dikomputer. Setelah mempelajarinya, siswa diperintahkan untuk mencoba bayangkan langkah-langkah yang ada dalam prosedur tersebut. Studi tersebut menunjukkan bahwa menginstruksikan pelajar untuk membayangkan solusi yang telah dipelajari sebelumnya menghasilkan hasil belajar yang lebih baik. Namun, teknik berimajinasi hanya bermanfaat bagi pelajar yang memiliki pengatahuan awal. Hasil penelitian menunjukkan bahwa teknik berimajinasi tidak berguna untuk siswa berpengetahuan awal rendah karena akan menghasilkan beban kognitif yang berat (Sweller et al , 2011). Untuk membayangkan prosedur atau konsep, peserta didik harus mampu memprosesnya prosedur atau konsep dalam memori kerja. Tindakan pemrosesan dalam memori kerja harus membantu dalam transfer ke penyimpanan memori jangka panjang. Tetapi pada pembelajaran diawal, membayangkan prosedur atau konsep mungkin sulit atau tidak mungkin, membuat instruksi imajinasi relatif tidak efektif. Oleh karena itu, pengajaran konvensional untuk mempelajari materi lebih diutamakan untuk pembelajaran diawal.

Bagi siswa yang sudah memiliki skema prasyarat yang sesuai dalam memori jangka panjang untuk memasukkan elemen yang berinteraksi. Prosedur membayangkan memberikan latihan tambahan yang dapat mengarah pada otomatisasi skema. Efek imajinasi terjadi ketika membayangkan suatu prosedur atau konsep menghasilkan lebih banyak informasi daripada mempelajari prosedur atau konsep yang sama. Misalnya, pada masalah geometri tertentu terkait "sudut berlawanan adalah sama", siswa itu tidak perlu mempelajari dengan mengerjakan contoh soal, cukup membayangkan teorema yang digunakan.

\section{The Guidance Fading Effect / Efek Pemudaran}

Efek pemudaran dalam pembelajaran matematika bertujuan untuk meningkatkan pemahaman peserta didik. Efek ini diberikan dalam bentuk penggunaan contoh soal. Guru matematika biasanya memberikan contoh soal serta jawaban yang dituliskan secara detail dari setiap langkah pengerjaan hingga ditemukan solusi dari dari soal tersebut. Dalam pemberian contoh soal awal, biasanya langkah tersebut yang digunakan, namun untuk soal-soal berikutnya yang serupa guru matematika dapat menggunakan efek pemudaran sebagai cara untuk lebih mendorong siswa lebih cepat memahami konsep dengan cara menghilangkan bagian dari langkah yang runtut dengan tujuan langkah yang dihilangkan dibuat sendiri oleh peserta didik. 
Sebagaimana yang dijelaskan sebelumnya, bahwa pengenalan langkahlangkah pemecahan masalah dapat dilakukan secara bertahap. Awalnya, setelah contoh lengkap disajikan, contoh dapat diberikan di mana langkah solusi tunggal dihilangkan sehingga peserta didik diminta untuk menyediakan langkah itu sendiri. Untuk tahap selanjutnya, jumlah langkah yang harus diselesaikan sendiri oleh peserta didik tanpa bimbingan eksplisit dapat ditingkatkan hingga hanya pernyataan masalah yang tersisa dengan peserta didik diminta untuk menyelesaikan semua langkah (Renkl \& Atkinson, 2003). Efek pemudaran dapat diharapkan untuk mengurangi beban kognitif dan, sebagai hasilnya, meningkatkan pembelajaran. Misalnya, setelah melihat contoh yang dikerjakan secara penuh, pelajar hanya diminta untuk menyelesaikan satu langkah pada masalah berikutnya daripada mencari solusi untuk keseluruhan masalah. Dua jenis prosedur pemudaran telah diusulkan (Sweller et al, 2011). ada dua jenis efek pemudaran yaitu backward-fading dan forward-fading. Sebagai contoh strategi penyelesaian untuk masalah dengan menggunakan dua langkah sederhana dapat menggunakan prosedur backward-fading, sebagai berikut:

Tentukan berapa nilai a pada persamaan $(\mathrm{a}+\mathrm{b}) / \mathrm{c}=\mathrm{d}$.

Solusi

$(\mathrm{a}+\mathrm{b}) / \mathrm{c}=\mathrm{d}$

$\mathrm{a}+\mathrm{b}=\mathrm{dc}$

$\mathrm{a}=$ ?

Berbeda dengan prosedur backward-fading, di dalam prosedur forward-fading, solusi dalam menjawab contoh, pertama juga disajikan sebagai contoh hasil yang benar-benar dikerjakan, diikuti oleh tugas kedua dengan solusi untuk langkah pertama dihilangkan, dan langkah selanjutnya solusi untuk dua langkah pertama dihilangkan, dan seterusnya. Dengan menggunakan contoh di atas, dalam prosedur forward-fading mengharuskan peserta didik memberikan solusi untuk langkah pertama dengan langkah terakhir yang diberikan oleh guru, sebagai berikut:

Tentukan berapa nilai a pada persamaan $(a+b) / c=d$.

Solusi

$(\mathrm{a}+\mathrm{b}) / \mathrm{c}=\mathrm{d}$

$\mathrm{a}+\mathrm{b}=$ ?

$a=d c-b$ 
Kondisi backward-fading umumnya lebih efisien daripada forward fading, backward-fading membutuhkan lebih sedikit waktu untuk mempelajari contoh. Dari perspektif beban kognitif, kondisi backward-fading dimana pelajar memberikan langkah penyelesaian masalah terakhir dapat memaksakan beban kognitif yang lebih rendah daripada kondisi forward-fading dimana pelajar menyediakan langkah pemecahan masalah pertama, sebuah langkah yang seringkali merupakan langkah kritis dalam solusi keseluruhan.

\section{Kesimpulan}

Berdasarkan pembahasan sebelumnya, bahwa ketujuh strategi tersebut merupakan strategi yang dominan dan penting dalam pengembangan ilmu untuk mendesain pembelajaran khususnya materi matematika. agar penyampaian materi mudah dipahami sehingga dapat meminimlkan beban kognitif eksternal siswa. Hal ini secara otomatis akan menaikkan beban kognitif konstruktif yang dapat membantu siswa mengkonstruksi skema pengetahuan baru berdasarkan materi yang telah dipelajari.

\section{Daftar Pustaka}

Arikunto, S., \& Jabar, C. S. A. (2010). Evaluasi program pendidikan. Bumi Aksara Baddeley, A. (1999). Human memory. Allyn \& Bacon.

Baddeley, A. (2012). Working memory: theories, models, and controversies. Annual review of psychology, 63, 1-29. https://doi. org/10.1146/annurev-psych-120710-100422

Blegur, I. K., Oktaviani, N., \& Retnowati, E. (2011). Apakah strategi goalfree dapat memfasilitasi literasi matematika siswa. In Prosiding Seminar Nasional Matematika Dan Pendidikan Matematika (pp. 359-364).

Chen, O., Retnowati, E., \& Kalyuga, S. (2019). Effects of worked examples on step performance in solving complex problems. Educational Psychology, 39(2), 188-202. https://doi.org/10.1080/01443410.2018.1515891

Ausubel, D. P. (1978). The psychology of meaningful verbal learning. New York: Grune

Irfani, N., \& Retnowati, E. (2020). Using Worked Examples During Geometry Instructions. In International Joint Conference on Arts and Humanities 
(IJCAH 2020) (pp. 56-61). Atlantis Press. https://doi.org/10.2991/ assehr.k.201201.010

Irwansyah, M. F., \& Retnowati, E. (2019). Efektivitas worked example dengan strategi pengelompokan siswa ditinjau dari kemampuan pemecahan masalah dan cognitive load. Jurnal Riset Pendidikan Matematika, 6(1), 62 74. https://doi.org/10.21831/jrpm.v6i1.21452

Leahy, W., \& Sweller, J. (2016). Cognitive load theory and the effects of transient information on the modality effect. Instructional Science, 44(1), 107-123. https://doi.org/10.1007/s11251-015-9362-9

Ngu, B. H., Chung, S. F., \& Yeung, A. S. (2015). Cognitive load in algebra: element interactivity in solving equations. Educational Psychology, 35(3), 271-293. https://doi.org/10.1080/01443410.2013.878019

Paas, F., \& Kirschner, F. (2012). The goal-free effect. Encyclopedia of the sciences of learning, 2, 1375-1377.

Penney, C. G. (1989). Modality effects and the structure of short-term verbal memory. MemoryEGCognition, 17, 398-422. https://doi.org/10.3758/ BF03202613

Renkl, A., \& Atkinson, R. K. (2003). Structuring the transition from example study to problem solving in cognitive skill acquisition: A cognitive load perspective. Educational psychologist, 38(1), 15-22.

Retnowati, E. (2008). Keterbatasan memori dan implikasinya dalam mendesain metode pembelajaran matematika. In Prosiding Seminar Nasional Matematika dan Pendidikan Matematika (pp. 978-979).

Retnowati, E., Sweller, J. \& Ayres, P. (2008). Group work settings: Worked example vs. problem solving. Online Proceeding of International Conference on Cognitive Load Theory 2008, http://www.uow.edu.au/conferences/ Cognitive_Load_Theory_2008/program.html

Sugiyono. (2012). Metode penelitian kuantitatif kualitatif dan REDD. Alfabeta.

Sweller, J. (1999). Instructional Design in Technical Areas. Australian Council for Educational Research.

Sweller, J. (2010). Element interactivity and intrinsic, extraneous andgermane cognitive load. Educational Psychology Review,22, 123-138. https://doi. org/10.1007/s10648-010-9128-5

Sweller, J. P., Ayres, P., \& Kalyuga, S. (2011). Explorations in the learning sciences, instructional systems and performance technologies, cognitive load theory. 
Humanika, Kajian IImiah Mata Kuliah Umum, Vol. 21. No. 1. (2021), 17-32

Springer.

Sweller, J., \& Chandler, P. (1994). Why some material is difficult to learn? Cognition and Instruction, 12(3), 185-233. https://doi.org/10.1207/ s1532690xci1203_1

Sweller, J., Ayres, P., \& Kalyuga, S. (2011). Facilitating effective mental processes: The imagination and self-explanation effects. In Cognitive Load Theory (pp. 183-192). Springer.

Sweller, J., Ayres, P., \& Kalyuga, S. (2011). The guidance fading effect. In Cognitive Load Theory (pp. 171-182). Springer.

Zed, M. (2004). Metode penelitian kepustakaan. Yayasan Obor Indonesia 